\title{
MPs and KM: How Strict ICT Policy Has Enabled Development of Personalized KM Services in the Parliament of Finland
}

\author{
Olli Mustajärvi \\ The Parliament of Finland, FIN-00102 Helsinki \\ olli.mustajarvi@eduskunta.fi
}

\begin{abstract}
The Parliament of Finland has launched active development of KM services. The cornerstones of the development have been the following characteristics: strict and centralized ICT-policy, ambitious visions and focused development plans, determined building of applications and services, open standards (e.g. SGML) in information production and utilization and openness in Parliament's web services. The KM projects of the Parliament have assessed the effects of $\mathrm{KM}$ on work cultures, produced a vision for practical KM activities, made concrete functional targets and means of action, and provided a basis for further KM development. The MPs have piloted the electronic workplace for the committee work, mobile services and first parts of MPs' personal toolbox. Perhaps the most interesting results are connected with the personal missions of MPs. The final result of this development is personalized KM and ICT services for MPs.
\end{abstract}

\section{Introduction}

National parliaments utilize information and communication technology (ICT) widely and diversely. This can be noticed clearly for instance in the biennial ICT conferences of Nordic Parliaments 1988-2000 and in the annual ICT conferences of ECPRD (the European Centre for Parliamentary Development and Research) 1990-2001. However, there are only a few reports, which describe the utilization of KM in Parliaments.

MPs utilize ICT for administration, communications and information management, both information gathering (research) and dissemination (publishing). "Using ICTs to do an existing job better is not however sufficient. MPs must respond to the use of ICT by those outside Parliament, including developments such as on-line democracy." [2].

E-government and e-democracy are complex information intensive and wide areas so we must use the modern solutions and innovations of ICT. Perhaps the most important "tool" is Knowledge Management [1]. The following definition of KM has been accepted in the Finnish Parliament's KM project [3]:

"Knowledge Management consists of systematic development and management of the knowledge, competence and expertise possessed currently by the organisation, and that being acquired by it in future. To be capable of managing knowledge, an organisation must be aware of what knowledge it has, where this knowledge resides,

The original version of this chapter was revised: The copyright line was incorrect. This has been corrected. The Erratum to this chapter is available at DOI: 10.1007/978-3-540-44836-5_33

M.A. Wimmer (Ed.): KMGov 2003, LNAI 2645, pp. 100-105, 2003.

(C) Springer-Verlag Berlin Heidelberg 2003 
and how to access the knowledge in question. Practical measures within knowledge management are especially knowledge acquisition, processing, storage and distribution. Increasing the effectiveness of knowledge dissemination and sharing is the only way for an organisation to increase remarkably its knowledge."

\section{The Case Environment}

The Finnish Parliament has 200 MPs and employs 600 civil servants. The unicameral Parliament was established in 1906. It enacts legislation, decides on taxes and state expenditures. It oversees the ministries and their subordinates and approves international treaties. Parliament also participates in the national preparation of EU affairs www.eduskunta.fi).

ICT era started in Parliament in 1985 when the strategy for the development of IT systems for parliamentary work was accepted [4]. From the very beginning development and utilization of ICT has been based on information processes.

Among other things this innovative development enabled close integration on session hall systems with the plenary session work in 1992 and the rapid adoption of Internet-based www-technology in 1995 when production databases were connected directly to www-servers. With the help of Parliament's www-service citizens can see very accurately and without delay what is going on in Parliament: for instance the agendas of sessions and committee meetings, MPs'speeches, voting results and all parliamentary documents are available in Internet -Parliament is really in a glass cage. Parliament's web-service has often received recognition for its advanced and wide content of information, for instance [9]. A structured document standard (SGML/XML) was adopted for document production, which means that knowledge produced by Parliament is now available in an easy-to-use form for in-house and external use. This forms a base for managing and utilization Parliament's own information, a part of its KM [10]. In addition, structured legislative documents have enabled the semiautomated consolidation of the Finnish jurisdiction database. This database is open to all and can be used without costs (service was opened in $2^{\text {nd }}$ Feb 2002, www.finlex.fi .

\subsection{MPs and ICT}

MP Suvi Linden has researched how MPs do their job and manage information in "the new ICT world" [7]. The results of research were that when the use of ICT increased the ICT services and tools became more useful, even necessary. At the same time there were more and more people involved to work with MPs -so active MPs build networks by the help of ICT.

\subsection{ICT Policy}

The organisation of ICT in Parliament has been centralized. Some benefits have been achieved, for instance common ICT standards, an effective way to utilize knowledge and bulk discounts on purchases. On the other hand centralized policy can cause some 
disadvantages, for instance ICT department does not fully understand business processes and it can be unclear who owns ICT applications.

Centralized services are for instance infrastructure, the main parliamentary applications, the purchase of ICT ware and training.

\section{$3 \mathrm{KM}$ in the Parliament}

\subsection{ICT and KM}

Parliament has excellent preconditions for its KM. Intranet (The Fakta system) is a central distribution channel for all information. For the most part, all written material produced by Parliament is accessible through this network, mainly in the form of structured documents. In addition, most of the Parliament's ICT infrastructure is of a high standard and well-functioning

\subsection{KM Project}

The Parliament's KM project was carried out during the period September 2000March 2001. The project objective was to produce a vision for practical KM activities, to make concrete functional targets and means of action, and to provide a basis for further KM development. MPs and their personal assistants were involved in this work in the capacity of clients, as one project team. The main results are set out in a reform programme in which necessary activities have been described [3]. The results of KM project have been published in a book "Developing and Implementing Knowledge Management in the Parliament of Finland" [11].

Most activities of the reform programme are directly connected with the MPs' and their assistants' work and services offered to them. MPs have piloted the new electronic workplace for committees. In the mobile pilot ICT services and electronic workplace has been utilized by means of different mobile devices [8].

\section{MPs' Missions}

In the KM project one project team was MPs' and their personal assistants' team (12 people together). In the team's opinion people's ability to manage an increasing amount of the information, information deluge, is the problem of KM. Thinking the solution to the problem, "...a team of MPs decided to propose a new approach where each MP individually defines his or her own personal mission. Subsequently, these definitions would be used as aids in various KM processes. A mission is an MP's personal description of the essentials and core interest areas in his or her work." [11]. Four MPs in the team described their personal missions in the mind-map form.

Every MP has responsibility to make her/his own mission. The goal is to make all missions according to the same framework, which would make it easier to utilize 
missions in production of shared profiled services. Missions are made on the voluntary base.

It is very interesting to think, what missions of groups (parliamentary groups, committees, citizens etc) could be and would it be possible to utilize them in the same way as personal missions?

\section{Utilization of MPs' Missions}

Among others, the MP's mission can be exploited in the following areas [3]:

- to organise MP's personal work

- database structures

- e-mail organisation

- paper document archives

- to facilitate co-operation between MPs and their personal assistants

- to describe MP's duties

- to make easier co-operation with MPs and civil servants

- for developing profiled information services for the Parliamentary groups or committees

- for making a common concept for all services

The earlier mentioned MPs' team has started to develop and pilot the utilization of MPs' missions. In the team there are four MPs and their personal assistants. According to the first discussions, the biggest problems are: How MPs could best use information systems and manage basic information management operations, what to do with the information deluge (e-mail) and the vast area of parliamentary affairs.

Perhaps the most interesting possibility to utilize missions is to create personal interfaces for information retrieval and management. These interfaces, the trees of information/knowledge, are in a mind-map form. Information has been organised in the trees according to the missions.

In this phase, the personalized interfaces have been implemented and updated manually by Parliament's ICT office in co-operation with information service because the available automated solutions were not suitable for Parliament's present ICT solutions.

At least in principle Parliament's information services must cover all activities of the society. When information services are divided into small components, it is possible to build personalized and profiled services by the help of these components, for committees, parliamentary groups and MPs. Both the producer and the user get benefit: The producer is able to produce customized services instead of standard services with the same resources and on the other hand users will have solutions to the information deluge (at least partial solution). Now, in this phase, it seems to be reasonable that only certain parts of personalized services will be realized in the near future, for instance parts of news services, document management and Internet information services. Profiled services have been piloted successfully for the Committee for the Future [8]. The purpose is to take these profiled services in use in every committee this year. 


\section{Outcomes and Lessons Learned}

I think that the strict and concentrated ICT policy has made it possible to build a good base for common services (information systems, data bases, personalized and profiled information services, infrastructure etc). Would it be the same situation with decentralized policy? Probably it would quite different, departments would have their own information systems, there would be no common databases and so on. Many visitors from different government and private organizations have told that the situation in their organizations is much worse and for instance it is almost impossible to establish really useful www-services -because of all information was spread all over the organization.

How is this in a large scale? How should e-government services be developed in society, a centralized or decentralized model? At least in Finland the biggest problem in e-government is that almost all services have been developed vertically, every ministry has been very active but more horizontal cooperation would have been needed. I believe that we would have a much better situation if the government had strict, also horizontal ICT policy and there would be real leadership somewhere in government. Probably plenty of resources have been used inefficiently.

One interesting model for e-government services and platform have been developed in the research project supported by European Commission [6]. In the project it has been created also a new GovML description language (based on XML). It is interesting to notice similarities with the results of Eulegis project. Eulegis was started by the initiative of the Finnish Parliament and supported by European Commission. Eulegis developed a prototype by which all EU and EU national legislative databases could be connected for searching and utilizing purposes [5]. Perhaps something like this would be needed for the whole e-government strategy.

I think that this KM project and pilots have been really a good start to develop better services. Some piloted services and solution have been taken into production use after parliamentary election (March 2003). We have established a new MP team which will start to develop MPs' workprocesses and solutions to master information and knowledge. In addition to these eGovernment type activities we have to develop also eDemocracy activities and solutions. I think that the results of KM project form a good basis for more demanding eDemocracy progress.

\section{References}

1. Burden, P.R., MacIntosh, M. and Srikantaiah, T.K. Knowledge management : the bibliography. Information Today, Medford, NJ, 2000.

2. Campbell, A., Harrop, A. and Thompson, B. Towards the Virtual Parliament - What Computers can do for MPs. Parliamentary Affairs, 52 (3).

3. Eduskunta Eduskunnan tiedon ja tietämyksen hallinta [knowledge management in the Finnish parliament]. Eduskunta, Helsinki, 2001.

4. Eduskunta Automaatiotyöryhmä Eduskunnan lainsäädäntötyöhön liittyvän tietojenkäsittelyn kokonaistutkimus [IT strategy of the Finnish Parliament]. Eduskunta, Helsinki, 1985.

5. Eulegis-project. European User Views to Legislative Information in Structured Form (EC DGXIII/AD4002) -project documentation, European Commission, 2000. 
6. Glassey, O., A One-Stop Government Architecture based on the GovML Data Description Language. in 2nd European Conference on e-Governance ECEG 2002, (St Catherine's College Oxford, United Kingdom, 2002), MCIL.

7. Linden, S. Kansanedustajan työn tiedonhallinta vuorovaikutusympäristössään uuden tietoja viestintätekniikan valossa [MP's information management in the era of new ICT]. University of Oulu, Department of Information Processing Science, 1998.

8. Mustajärvi, O., The Information Needs of MPs as a basis for the New Electronic Workspace: A Finnish Case Study. in 2nd European Conference on e-Governance ECEG 2002, (St Catherine's College Oxford, United Kingdom, 2002), MCIL.

9. Ronaghan, S.A. Benchmarking E-government: A Global Perspective. United Nations, DPEPA, New York, 2002.

10. Salminen, A., Lyytikäinen, V., Tiitinen, P. and Mustajärvi, O., Experiences of SGML standardization: The case of the Finnish legislative documents. in Proceedings of the 34th Annual Hawaii International Conference on System Sciences, (Maui (HA), 2001), IEEE Computer Society Press.

11. Suurla, R., Markkula, M. and Mustajärvi, O. Developing and Implementing Knowledge Management in the Parliament of Finland. Parliament of Finland, Helsinki, 2002. http://www.eduskunta.fi/fakta/vk/tuv/KM_Finnish_Parliament.pdf 